\title{
GENERAL AND PARTICULAR ASPECTS OF INFECTIVE RISK IN ORTHODONTICS AND DENTOFACIAL ORTHOPEDICS - PART II
}

\author{
CRISTINA NICOLETA MIHAI ${ }^{1}$, DRAGOȘ STANCIU ${ }^{2}$, GABRIEL CIOCHINDĂ ${ }^{3}$, \\ MIHAI BURLIBAȘA ${ }^{4}$, VIOREL ȘTEFAN PERIEANU ${ }^{5}$, MARIANA PĂCURAR ${ }^{6}$, \\ IRINA ADRIANA BEURAN ${ }^{7}$, IRINA DONCIU ${ }^{8}$, ILEANA IONESCU ${ }^{9}$, MĂDĂLINA VIOLETA \\ PERIEANU $^{10}$, LILIANA BURLIBAȘA ${ }^{11}$, GABRIELA TÁNASE ${ }^{12}$, LAURA LELIA MIHAI ${ }^{13}$ \\ 1,2,3,4,5,7,8,9,10,12,13 “Carol Davila” University of Medicine of Pharmacy Bucharest, ${ }^{6}$ UMFS “George Emil Palade” Târgu-Mureș, ${ }^{11}$ University of \\ Bucharest, ${ }^{14}$ Private practice, Bucharest
}

\begin{abstract}
Keywords: orthodontics Abstract: The infectious risk in the dental practice, including in the orthodontic practice, represents a and dentofacial real danger for both the medical team (orthodontic specialist, dental nurse and dental technician), but orthopedics, infectious also for the patient. But, dental orthodontics and dentofacial orthopedics is a specialty in the field of risk, medical team dentistry with a special content and special instruments and, therefore, by conducting this study, even if it is only preliminary, we set out to highlight a succession of concepts, the objective being to familiarize the specialists in orthodontics and dentofacial orthopedics with certain rules with theoretical and practical character, which aim to prevent and combat the infectious risk in orthodontic practice.
\end{abstract}

\section{INTRODUCTION}

As we have already mentioned in the first part of this material, any person who carries out a professional activity, is permanently or temporarily, from the point of view of his health, under the influence of a complex of hazardous factors specific to each job, which can lead either to professional illnesses, medically or legally defined or not, either to physical, chemical and biological incidents or accidents. In this situation, there is also the dentist, regardless of the specialty he has (general dentistry, orthodontics and dento-facial orthopedics, dentoalveolar surgery, endodontics, periodontology) who, through his activity in the dental office, is under the influence of some specific hazardous factors, the most important being the infectious one.(1-8)

\section{AIM}

Practicing the dental profession in dental office and in dental laboratory implies an infectious risk, which is permanent and affects the staff and also, the patients. When we are discussing about dental profession, we also refer to orthodontics and dento-facial orthopedics, one of the main specialties of this medical field, which is dental medicine. Practically, any person present in a medical office with dental profile (including orthodontics and dental-facial orthopedics), loads the professional environment with various pathogenic bacteria and viruses, and the specific activity in such a cabinet, can inevitably open entrance doors for infectious agents.(1-8) Thus, in a dental office (also, in an orthodontic and dento-facial orthopedics office), in the air inhaled by the professionals who carry out their activity here, a multitude of pathogenic or non-pathogenic microorganisms can be found on the following supports:(1 -8)

- Mineral, animal or vegetable powders of very different sizes, on the surface of which microorganisms are adsorbed and concentrated, and depending on their size, sediment quickly;

Flügge drops issued by any person through physiological and/or pathological acts. These drops are large, sediment quickly and usually are not inhaled.

Condensation nuclei (or droplets nuclei) which, in relation to atmospheric humidity, are partially dehydrated and can be easily inhaled. These particles play the most important role in the transmission of viruses and bacteria from the bronchial tree to the alveoli of the pulmonary parenchyma.

Infectious agents in the air can vary quantitatively and qualitatively, in relation to the human activities carried out in that environment and the microbial load of the environment.

As mentioned in the first part of this report, by conducting this study, even if it has only a preliminary character, we want to highlight a succession of notions, the aim being to familiarize the specialists in orthodontics and dentofacial orthopedics with certain rules of theoretical and practical nature, which aim to prevent and combat infectious risk in orthodontic practice.

\section{MATERIALS AND METHODS}

In the first part of this material, we approached the issue of the medical practice where orthodontic and dento-facial orthopedics work, as well as aspects related to a part of the instruments used in this specialty. In the following, we will discuss the other categories of instruments used in the specialty of orthodontics and dento-facial orthopedics, not covered in the first part of the report, as well as the particularities of the orthodontics and dento-facial orthopedics specialty.

\section{Instruments (continued):(1-8)}

1. The arch wires are usually delivered in plastic tubes. The chosen arch wire is cut with the help of a pliers intended for

${ }^{4}$ Corresponding author: Mihai Burlibaşa, Str. Plevnei, Nr. 19 Sector 1, Bucureşti, România, E-mail: mburlibasa@gmail.com, Phone: +40723472632 Article received on 02.05 .2020 and accepted for publication on (will be filled out by the Editorial team) 


\section{CLINICAL ASPECTS}

this maneuver and is never used in the oral cavity. The jaws of these pliers were previously disinfected, with the help of chemicals with disinfectant potential, in accordance with the current Romanian legislation. Under these conditions, the portion of the arch wire which remain uncontaminated can be kept in the plastic tube without special treatment. Preformed arch wire are supplied in packs of 10 pieces. If the springs are individually packed, the risk of microbial contamination is virtually zero. Otherwise, what happens most often, they must be removed from the package with the help of a forceps.(1-8)

2 . The ligatures. There are three types:(1-8)

- Stainless steel ligatures, preformed, short or long, which are delivered in tubes or boxes. These are sufficient in number, theoretically uncontaminated, and the remaining unused, can be kept for future sessions.

- The individual elastomeric ligatures are delivered in the form of minibars, for an entire arch. If the product is delivered in longer bars, the desired length can be cut before the start of treatment and the ligatures are kept in the patient's box for a later session.

- Elastomeric chains are delivered in rolls. It would be best for the cabinet nurse to prepare chains of the desired length, which will be kept in special boxes. They will be delivered to the orthodontic specialist, with the help of a forceps.

The particularities of the orthodontics and dentofacial orthopedics specialty:

1. Infectious risk. It is difficult to answer the question "how serious is the infectious risk in orthodontic practice?" It is certain that the infectious risk exists, therefore, personnel protection measures are required. But, over time, the idea was that, as long as the orthodontic and dento-facial orthopedics were only attended by children with good general health and usually treated with mobile devices, this infectious risk was quite small in magnitude. With the change of the age of the patients and especially by the extension and even the generalization of the fixed orthodontic techniques, which can frequently cause the appearance of bleeding, things have evolved. Specifically, through orthodontic procedures, it has become possible to transmit viruses, such as hepatitis $\mathrm{B}$ and $\mathrm{C}$ viruses (HBV and $\mathrm{HCV}$ ), human immunodeficiency virus (HIV), cytomegalic virus, herpes virus, etc. However, in offices with a profile of orthodontics and dento-facial orthopedics it is advisable, besides prudence, to ensure an increased hygiene: the simple "clean" aspect visible with the naked eye is not enough, but it must go to surface decontaminatio and sterilization of materials and part of specialized equipment, when they allow and in full accordance with the Romanian legislation.(1-8)

2. Protection of specialized personnel. Although it is true that the vast majority of the patients of the orthodontic specialist remain children and adolescents, who should not be frightened by a too impressive decor, however, the measures required for the protection of the members of the medical team, but also of the patients, do not differ from those practiced in a classic dental office. It is extremely important that:(1-8)

- the specialized personnel have a work outfit, including shoes, easy to wash and that can be changed as often as possible (we discuss here even those disposable paper robes)

- the examination gloves should be changed after each patient;

- the wearing of mask and protective glasses should be compulsory, during working sessions;

to perform a thorough hand washing before applying gloves.

3. The nature of maneuvers in orthodontic practice. With the exception of the conventional equipment and the dental unit, the materials used in orthodontic practice are classified in the "semi-clinical" category. But, as this instruments may also come in contact at a certain time with the biological fluids of the oral cavity (saliva, blood, crevicular fluid etc.), it must be decontaminated, disinfected and sterilized after each use, in accordance with the specialized legislation in Romania. However, in a strictly professional sense, the therapeutic acts performed in dental offices with orthodontic and dento-facial orthopedics profile, do not belong to those form the "critical" category.(1-8) But in order to better understand these aspects, a brief explanation of these notions is needed, namely: medical surfaces are called "critical", "semi-critical" and respectively, "non-critical". The selection of the closest disinfection procedure for the last category (non-critical) will include considerations about the nature of the surface, as well as the type and degree of contamination:(1-8)

Critical: instruments that pass through soft tissue or bone. They must be sterilized after each use. Examples: scalpel, bone burs, scissors;

- Semicritical (mirrors, ball brunishers, Hideman spatula), who come into contact with oral tissues. They must be sterilized after each use; In the case of thermosensible ones, high-grade disinfection is practiced.

Non-critical: they come in contact with the intact skin. Use medium or low level disinfection or just washing with detergent and water.

Returning to the problems that strictly interest the orthodontics and dento-facial orthopedics, it should be noted that, the orthodontic specialist does not penetrate either soft gingival tissues or hard tissues. However, during certain sessions, bleeding occurs constantly. In particular, it is about applying and removing the orthodontic rings from the posterior teeth, but also about the mechanical brushing of the teeth. As a result, by analyzing the most common gestures, such as choosing a ring from a set, adjusting the dental examination lamp, or opening a box, after the fingers have been inserted into the patient's oral cavity, we will notice that they also contribute to microbial contamination of surfaces and of related instruments.(1-8) At the same time, it is extremely important for the orthodontic practitioner to develop a program for cleaning and disinfection of surfaces, as well as for sterilizing the instrument, in accordance with the Romanian law.(1-8)

Specifically, the orthodontic practitioner should not assign these tasks to inexperienced and unskilled personnel because they risk living in a state of false security. The responsibilities are shared by everyone: from the front desk personnel to cleaning crew and dental nurse. The orthodontic practitioner is obliged to get directly involved in the implementation of the established program.(1-8)

The problem of hazardous waste in dental offices with orthodontic and dento-facial orthopedics profile is identical to that of the general dentistry and/or dento-alveolar surgery offices and complies with the legislation in force in Romania. Thus, "traumatizing" waste, cutting or stinging (orthodontic rings, attachments, metal ligatures, springs) as well as the contaminated ones (rolls or compresses, which came in contact with the biological fluids of the oral cavity: saliva, blood, crevicular fluid etc.), are classified as "high risk" waste. These are in fact classified as "hazardous waste" and will be collected, transported and destroyed, according to the rules in force in our country. $(9-21)$

As in the first part of this material, starting from these notions regarding the infectious risk and its prevention in orthodontics and dento-facial orthopedics, we developed a questionnaire consisting of 7 items, which we applied to a number of 19 specialists in orthodontics and dento-facial orthopedics in Romania, with ages between 28 and 62 years, the gender distribution of the subjects included in the study being as 


\section{CLINICAL ASPECTS}

follows: 14 doctors $(73.68 \%)$ were females, while 5 orthodontic practitioners $(26.32 \%)$ were males (figure no. 1 ).

Figure no. 1. Gender distribution of subjects involved in the study

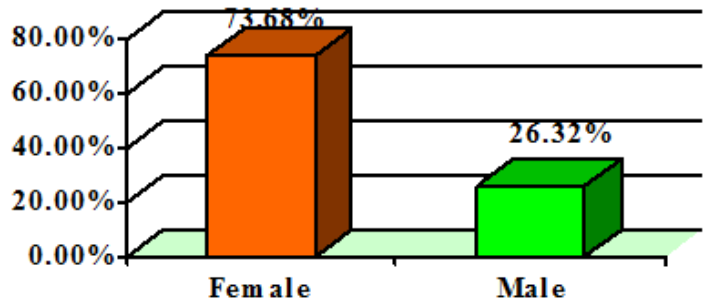

Next, we will present the questionnaire applied to the 19 subjects:

1. In the air inhaled by dental specialists in the environment in which they operate, a multitude of pathogenic or nonpathogenic microorganisms can be found on the following supports? a. Mineral, animal, vegetable powders; b. Flugge drops; c. Condensation nuclei; d. Microbial supports. Correct answers a, b, c.

2. The disinfection of arch wires can be carried out in the following way? a. With the help of chemicals with disinfectant potential, in accordance with the current legislation in Romania; b. With the help of moist heat; $\mathbf{c}$ With the help of dry heat. Correct Answer: a.

3. In orthodontic practice, the ligatures can be? a. Metallic, preformed, short or long, which are delivered in tubes or boxes; b. Elastomeric, individual and are delivered in the form of minibars, for an entire arch; c. Elastomeric chain: delivered in rolls; d. From hydrophilic cotton and is it delivered in rolls. Correct answers a, b, c.

4. Through orthodontic maneuvers, it has become possible to transmit the following species of micro-organisms? a. Hepatitis $\mathrm{B}$ and $\mathrm{C}$ viruses (HBV and HCV); b. Human immunodeficiency virus (HIV); c. Cytomegalic virus and herpes virus; d. Saccharomyces cerevisiae. Correct answers: $\mathbf{a}, \mathbf{b}, \mathbf{c}$.

5. The protective measures, regarding the prevention of the infectious risk in the orthodontic practice, are the following? a. The specialized personnel must have a work outfit, including shoes, easy to wash and which can be changed as often as possible (we discuss here and about those disposable paper robes); b. Examination gloves should be changed after each patient; $\mathbf{c}$. The wearing of the mask and the goggles shall be obligatory during the working sessions; $\mathbf{d}$. A thoroughly wash of hands should be taken before applying gloves. Correct answers: a, b, c, d.

6. In the current dental practice and therefore also in orthodontics and dentofacial orthopedics, depending on how the procedures for decontamination, disinfection and sterilization must be applied, the surfaces are divided into? a. Very critical; b. Critical; c. Semicritical; d. Non-critical. Correct answers: $\mathbf{b}, \mathbf{c}, \mathbf{d}$.

7. Among the specific maneuvers of the orthodontic and dento-facial orthopedics activity, the following are considered as potentially bleeding maneuvers? a. Applying and removing the orthodontic rings on the posterior teeth; b. Choosing a ring from a set; c. Adjusting the dental examination lamp; d. The mechanical brushing of the teeth. Correct answers: $a, d$.

\section{RESULTS AND DISCUSSIONS}

To the first question related to the airborne supports on which the microorganisms can be found, most of the subjects included in the study correctly answered variants $a, b$ and $c$
(73.68\%). Only 5 subjects (representing 26.32\%) chose in addition to the correct variants and the answer d (figure no. 2).

Figure no. 2. Analysis of the airborne support on which microorganisms can be found

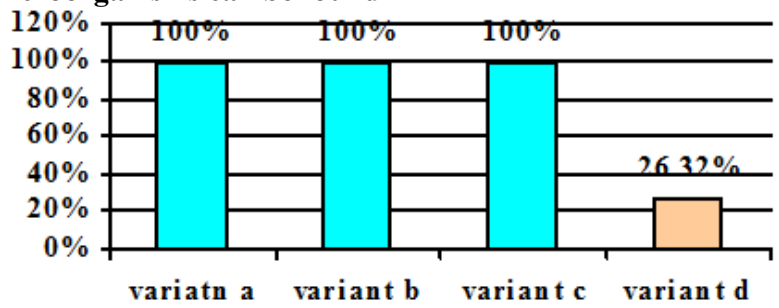

Regarding the way of performing the disinfection of orthodontic arch wires, 16 practitioners (representing 84.21\%) responded correctly, namely substances with disinfectant potential, and only 3 practitioners answered incorrectly (figure no. 3).

Figure no. 3. Disinfection of orthodontic arch wires

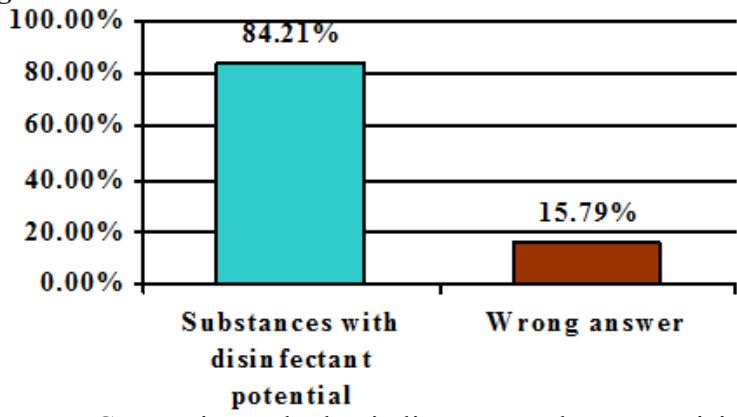

Concerning orthodontic ligatures, only one participant responded incorrectly, including hydrophilic cotton as a material (figure no. 4), but we can put this answer on the age of the respondents.

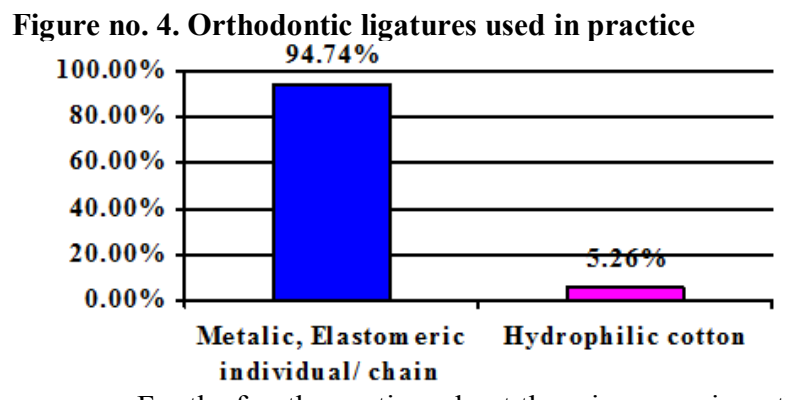

For the fourth question, about the microorganisms that can be transmitted through orthodontic maneuvers, most subjects answered correctly (variants a, b and c, 84.21\%) and only 3 subjects (representing $15.79 \%$ ) included beside the correct variants and the answer d (figure no. 5).

Figure no. 5. Microorganisms transmissible through orthodontic procedures

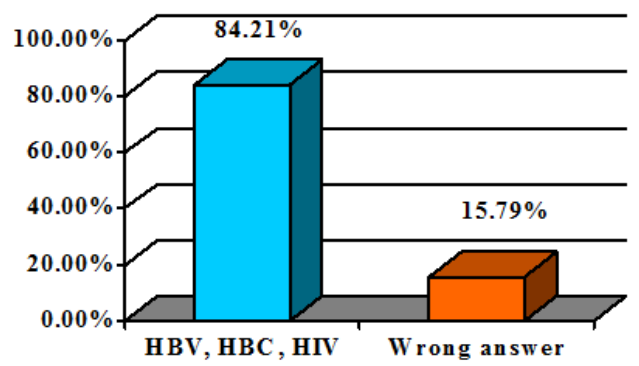


We are pleased to note that all study participants responded correctly with regard to protective measures to prevent infectious risk.

At the sixth question concerning how the surfaces are divided according to the procedures for decontamination, disinfection and sterilization, about half of the respondents answered correctly (variants b, c and d, - representing 52.63\%). The rest of the respondents considering that a broader classification is needed (they have ticked all the answer variants) (figure no. 6).

Figure no. 6. Classification of the surfaces according to the hygiene procedures

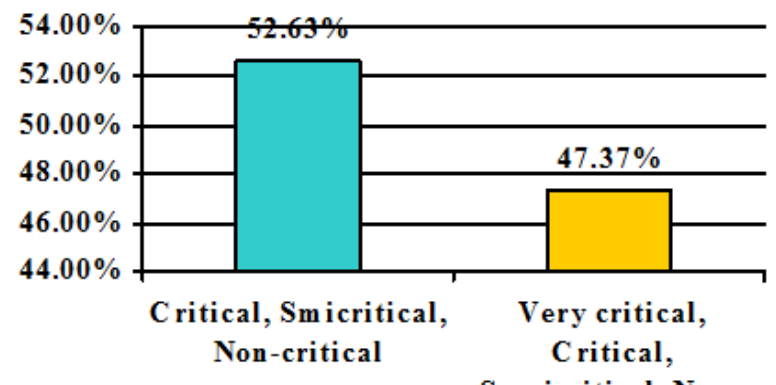

Semicritical, Non critical

At the last point of the questionnaire about specific orthodontic procedures with bleeding character, all the study participants answered correctly (applying and removing orthodontic rings and mechanical brushing of the teeth).

\section{CONCLUSIONS}

After studying the answers to the 7 questions, we can conclude several aspects, some extremely interesting, as follows:

About a quarter of the subjects included in the study make serious confusions to certain notions of general microbiology, notions that are studied in the first years of university studies and which at this point should be part of the general medical culture of each dentist, regardless of its specialty.

All the specialists in orthodontics and dentofacial orthopedics included in the study, have both theoretical and practical firm knowledge regarding both the common dental instruments and the specialized instruments described in this second part of the report (arch wires, ligatures) etc.

Most orthodontic specialists involved in the study (over $84 \%$ ) are aware of the possibility of transmitting high risk viruses through specialized maneuvers: hepatitis $\mathrm{B}$ and $\mathrm{C}$ viruses (HBV and $\mathrm{HCV}$ ), Human immunodeficiency virus (HIV) virus cytomegalic, of the herpes virus.

The materials and instruments are stored in specially arranged places, in enclosed spaces, protected from air and moisture. In order to make an efficient rotation of the stock, it is good to rule "first in first out".

If the orthodontic practitioner carries out his activity alone in the specialized office, without the benefit of a medical assistant, he will face many difficulties in maintaining an increased level of asepsis, risking not have time to deal in an appropriate way patients. Under these conditions, the orthodontic specialist will be obliged to make a series of compromises, which are not always in accordance with the legal legislation of our country.

Although, the costs seem quite high, the absence of a medical assistant (auxiliary staff), can be compensated by using disposable materials and tools and disposable protections, for the areas classified as "critical" of the equipment and work surfaces.

Also, if the orthodontic practitioner does not benefit in the professional activity from the help of a dental nurse, it is necessary that the installation of the decontamination and washing area of the instrumentation be carried out even in the professional work area of the cabinet, in order to avoid trips to other rooms, between 2 patients.

Also, in the absence of the auxiliary personnel, the packaging of the instruments in special bags or sterile paper towels, can be done during the breaks between the consultation and/or treatment sessions, while the actual sterilization process can be postponed until the end of the working program, if the number of tools allows it.

Acknowledgement: In this article, all the authors have equal contribution with the first author.

\section{REFERENCES}

1. Burlibaşa M, Dobrovolschi O, Dincă M, Dobrovolschi T, Onisâi L, Sfarghiu L, et al. Ghid practic pentru asistentele de medicină dentară (vol. I). Ed. Universităţi Transilvania, Braşov; 2011.

2. Carabela M, Burlibașa M. Hygiene, aseptic, antiseptic in oral implantology. Bucharest, Docendi Ars Publishing House; 2006.

3. Burlibaşa M, Carabela M, Moraru L, Dincă M, Ionescu I. Decontaminarea amprentelor în practica stomatologică şi în chirurgia maxilo-facială. București, Ed. Ars Docendi; 2004.

4. Burlibaşa M. Iniţierea, dezvoltarea şi combaterea biofilmelor microbiene formate pe suprafaţa materialelor de amprentă în reabilitarea implanto-protetică. București, Ed. Cermaprint; 2008.

5. Institutul Național de Sănătate Publică. Ordinul nr 961/2016. Institutul Naţional de Sănătate Publică. [Online] [Cited: december 13, 2019.] https://insp.gov.ro/sites/Biocide/public_html/Documente/Bi ocide/Ordin_961_2016.pdf.

6. Council on dental materials, instruments and equipment, Council on dental practice, Council on dental therapeutics. Infection control recommendation for the dental office and the dental laboratory. J Am Dent Assoc. 1996;116:241-248.

7. Council on scientific affairs and council on dental practice. Infection control recommendation for the dental office and the dental laboratory. J Am Dent Assoc. 1996;127:672-680.

8. Missika P, Drouhet $G$, et al. Hygiene, Asespsie, Ergonomie. Un defi permanent. Paris: Editions CdP, 2001.

9. Burlibașa M., Muntianu L., Tănase G., Bucur M.B., Comes C.A., Ionescu C.A. Study on microbial contamination of biomaterials in medical practice. Metalurgia International. 2010; Vol. XV, Spec. Issue No. 2, p. 163-166.

10. Tănase G, Burlibașa M, Muntianu L, Simion I, Bucur MB, Ionescu CA. Testing the antibacterial potential of biomaterials in medical practice. Metalurgia International. 2010; Vol. XV, Spec. Issue No. 2, p. 160-162.

11. Burlibaşa M, Tănase G, Muntianu L, Murgu AI, Teodorescu E, Malita C. Quality of life, a multidisciplinary concept with economic and social impacts in medical practice. Metalurgia International. 2010; Vol. XV, Spec. Issue No. 4, p. 88-90.

12. Mocuța D, Popovici IA, Burlibașa L, Cristache G, Sfeatcu $\mathrm{R}$, Bodnar T. Impact of the living conditions on population health. Metalurgia International. 2009;14:17-19.

13. Ispas DC, Eftene OA, Burlibaşa M, Bucur MB, Tănase G, Cristache CM. Implications of titanium in orthodontics and dental facial orthopedics. Metalurgia International. 2011;Vol. XVI, No. 10, p. 72-74.

14. Burlibaşa $M$, Cernușcă-Mițariu M, Burcea CC, Mițariu M, Ferechide D. Halogen compounds - theoretical, 
physiological and practical aspects regarding the decontamination, disinfection and sterilisation of intsruments and biomaterials in dental medicine practice. Metalurgia International. 2012; Vol. XVIII, Spec. Issue No. 3, p. 54-57.

15. Burlibașa $M$, Cernușcă-Mițariu $M$, Cernușcă-Mițariu S, Mițariu M, Malița M. Theoretical and practical aspects related to biomaterials decontamination in dental medicine (with reference to dental prosthetics). Metalurgia International. 2013; Vol. XVIII, No. 4, p. 261-267.

16. Burlibasa L, Domnariu C. Epigenetic landscape of human diseases. Acta Medica Transilvanica. 2018;23(2):33-37.

17. Bodnar DC, Burlibașa L, Vârlan C, Marcov N, Georgescu SR, Marcov CE. Mercury, biocompatibility and its impact on environment. Metalurgia International. 2009;14:95-100.

18. Cristache CM, Burlibaşa M, Cristache G, Drafta $S$, Popovici IA, Iliescu AA, et al. Zirconia and its biomedical applications. Metalurgia International. 2011; Vol. XVI, No. 7, p. 18-23.

19. Mihai A, Chifiriuc CM, Lazăr V, Stănescu R, Burlibașa M, Ispas DC. Microbial biofilms in dental medicine in reference to implanto-prostethic rehabilitation. Rev chir oro-maxilo-fac implantol. 2008;1(1):9-13.

20. Sfarghiu LG, Oancea L, Lițescu R, Burlibașa M, Moraru L, Perieanu VS, et al. The influence of disinfectants incorporation on die stone linear expansion. Romanian Biotechnological Letters. 2016;21(3):11585-11590.

21. Jamous S, Burlibaşa L. New insights in molecular analysis of gene regulation - an epigenetic overview. Letters in Applied Nanobioscience. 2018;(1-2):511-522. 